PART 2

Consensus as An Expression of Conflict 
Fariba Adelkhah - 9789004349551

Downloaded from Brill.com04/26/2023 10:44:13AM via free access 


\title{
War and State (Re)Construction in Afghanistan: Conflicts of Tradition or Conflicts of Development?
}

\author{
Fariba Adelkhah
}

\begin{abstract}
Foreign aid provided for the (re)construction of the Afghan state since 2001 has, paradoxically, intensified the 'ethnicisation' and sectarianisation of economic and political relations, contradicting the criteria of good governance advocated by donors. Conflicts apparently related to tradition and identity have become more common and indeed point to more fundamental contradictions between the culturalist representation of Afghan society and the effects of the country's integration into the world capitalist economy. Thus, viewing Islamic radicalisation, ethnic polarisation or tribal atavism as responsible for the social and political violence in Afghanistan gives an incomplete picture of the situation as it ignores transformations in society and the new challenges of this supposedly traditional conflict.
\end{abstract}

On 20 January 2014, a fight broke out between three people in the main thoroughfare of the bazaar of Bamyan, near the Azizi Bank. Before long, a hundred men had become involved in this altercation: they included inhabitants of the city but there were also men from surrounding areas-Asiyab, Shahidan, and Jagrakhil - and Fatmasti, the home town of the three protagonists located ten minutes' drive away on the road to Shashpul. What were they quarrelling about? Presumably a bag of money that one of them was taking to deposit at a bank. But as the subject of the dispute has vanished, and no one seems to want to talk about it today, it would be better to ask why the conflict intensified in

* My thanks to Mahdi Mehraeen (journalist and consultant) and Ibrahim Tavalla (editor of the weekly Sada-I Shahrvand-i Bamayn) for their help throughout this research project. I have simplified the transcription and accentuation of Dari for easier reading.

(C) FARIBA ADELKHAH, 2017 | DOI 10.1163/9789004349551_007

This is an open access chapter distributed under the terms of the prevailing CC-BY-NC license at the time of publication. 
the days that followed, when ever more men gradually arrived, spoiling for a fight, from Yakawalang, Kabul, Baghlan, and Mazar-i Sharif. To restore calm, at least momentarily, the prefecture (wilayat), the Council for Peace (Shora-i Solh) and the High Council of Ulamas (Shora-i Ulama) had to intervene jointly to impose, on the party held responsible for the renewal of violence, relatively high financial damages. It was stipulated that if any family took the initiative in reviving hostilities, it would be definitively deprived of any political and administrative positions it held. Although this agreement was based on the Koran, few residents of Bamyan thought that the case had been settled once and for all. Indeed, it was only the latest episode in a 30-year conflict that had cost the lives of 74 people. 'The same grandfather (padar kalan), the same mosque, the same religious membership, the same cemetery-except for five of the victims who were interred in another town in an attempt to heal the wounds', as I was told. Despite this, the dispute could still at any moment lead to a massacre.

The small town of Fatmasti is home to some 300 families. Since the 1970s, it has been the scene of 74 tragic deaths-martyrs for some, victims of murders for others-often within the same family, involving a series of vendettas. The residents of Fatmasti sometimes call themselves Hazara and sometimes Parsiwan, and claim they are Sabzevari from Iran. Their story is mentioned in the mausoleums of Mir Hashem Agha and Seyed Ali Yakhsuz Bamyan, the two main pilgrimage sites in the city. "The Hazaras are descendants of Genghis Khan the Mughal, but our origins date back to the dynasty of Key, a dynasty of aria (Aryans),' says Khalifa Aziz, ${ }^{1}$ the babeh kalan (the grandfather of the place), who no longer lives in Fatmasti and has lost most of his family in conflicts between cousins (mama and khala). Most of these violent deaths occurred during the jihad against the Soviets and the 'war of the commanders' (1992-96), during which his family split between supporters of Hizb-i Nasr-later absorbed by the Hizb-i Wahdat of Mohammad Ali Mazari-and the Hizb-i Harakat-i islami of Ayatollah Asef Mohseni. But the intra-family conflict was rooted in land demarcation (polvan), a process that has usually involved placing brothers-in-law (baja in Dari or yazna in Pashto) in competition with one another. The general opinion was that it was intensified by two factors specific to this time of war: the flow of arms and the political exile or economic emigration that were forced upon the men. So this was a war between cousins, fuelled by marital disputes. Tellingly, the men were the protagonists of the violence, but women cast an ubiquitous shadow. They contributed, indirectly, to the production of the society and its conflicts.

1 Personal observations, 2014 and 2015. 
Be that as it may, the division of Fatmasti between the two main Shi'ite political forces involved in the jihad was grafted onto older rifts. According to the young men in the village, who now longed to flee from it, residents had not been able to enjoy 'a single quiet night' since the mid-1980s. Fatmasti provided the jihad with its share of qumandan, but after 2001 it also provided the administration of the Karzai government with many of its local officials, whose decisions in turn fuelled resentment and vendetta. This war in Fatmasti was a small-scale replica of political life in Bamyan. In June 2015, the tumultuous appointment of the new prefect was a reminder of the persistent disputes between the Hazaras and among the Shi'ites, divisions inherited from jihad and a more ancient local history. This event also reawakened another dimension of the social history of Afghanistan: that of the arbaki. These 'protectors', who often created the need for the very protection they were supposed to provide, re-emerged in the form of proxy militias of the North Atlantic Treaty Organization (NATO), which Fatmasti supplied in great number. ${ }^{2}$

The village of Fatmasti, then, is a compendium of the complex social affiliations and political issues in contemporary Afghanistan, especially the central region of the Hazarajat on which we will be focussing. We will see that foreign aid provided since 2001 for the (re)construction of the Afghan state has paradoxically intensified the 'ethnicisation' and sectarianisation of economic and political relations, in total contradiction with the criteria of good governance advocated by the donors. Conflicts apparently related to tradition and identity have become more common, and indeed point to more fundamental contradictions between the culturalist representation of Afghan society and the effects of the country's integration into the world capitalist economy. Thus, viewing Islamic radicalisation, ethnic polarisation or tribal atavism as responsible for the social and political violence in Afghanistan gives an incomplete picture of the situation, as it ignores transformations in society and the new challenges of this supposedly traditional conflict. In addition, donors often use a naive language, trapped within general models and paradigms disconnected from the reality of the country whose problems they are attempting to solve.

\section{The Primordial Experience of War}

History, then, is essential if you want to understand Afghanistan. Ethnicity, language, tradition and even Islam cannot be considered as explanatory categories in themselves. We will start from the premise that the problems of

2 Personal observations, 2014 and 2015. 
Afghanistan's post-conflict reconstruction are part of the old, if constantly updated logics of which they are echoes, and into which they largely merge. And this is true even if the fight against the Taliban, the neo-liberal zeitgeist, and globalisation have given the military actors, non-governmental organisations (NGOs) and the diaspora an important role, in addition to or instead of governments and their public agencies of cooperation.

Before getting to the heart of the matter, it is worth mentioning the historical context in which foreign intervention in Afghanistan, one of the least developed countries in the world, has occurred. In 1978, the People's Democratic Party of Afghanistan fomented a coup that helped overthrow the government of President Dawood Khan and triggered a Soviet occupation that lasted until 1989 (Andishmand, 2009; Roy, 1985). Since then the country has been shaken by a civil war (1989-96) - including the Battle of Jalabad in 1989 and the successive battles of Kabul (jangha-ye kabol) between 1992 and 1996 (Qhodus, 2009; Azimi, 2012-2013; Dorronsoro, 2000) - and by foreign interventions. Afghanistan holds a sad record: in the 199os, the country produced the highest number of refugees in the world.

On Afghan soil, poverty and the presence of weapons have combined to exacerbate land issues, intensify urbanisation and swell migration. Since 2002, the problems arising from this conjunction, far from being resolved, have worsened, especially when it comes to property (Adelkhah, 2013). The Karzai Administration has merely endorsed the overlapping and layering of laws and regulations handed down from prior periods, pragmatically using, to its advantage, the local balance of power between institutions, between social and ethnic groups, and between commanders. In reality, over and above the makebelieve discourse presented to foreign donors, this policy has led to a centralisation of the land allocation process and then to land-grabbing on the part of those in power and their clientele, in their own names (or those of their families) and in the name of the state. From this point of view, the general relations maintained by both the dominant political class and the state with the mass of the population-especially with residents in rural, sedentary or nomad zones - is probably more important than the extent of interethnic or religious relationships, although they are often two sides of the same coin. The only major legislative reform in this area was passed in 2008 and aimed at the opening of the land market to foreign investors. Even if its application is still limited, this reform has created more problems than it has solved. It has absolutely not broken with the logics of accumulation of the national ruling class that controls the granting of agricultural and mining concessions, since this class still holds the keys to the market and the signing of contracts. If these foreign investments are indeed made, they will trigger the alienation of considerable 
amounts of land, to the detriment of small farmers and shepherds. Similarly, after the trauma of the destruction of the Bamyan Buddhas in 2001, 'cultural heritage' has been turned into a matter of creating sanctuaries: this measure, however laudable, was imposed by the government on powerless populations. Among its side effects, we can mention the fact that the Tajik lands in Bamyan can, because of this 'sanctuarisation', no longer be cultivated or built on even though the mountainous nature of the region does not make it possible for this land to be exchanged for other arable plots. ${ }^{3}$

Despite the superposition of texts, the heterogeneity of proofs of ownership, the coexistence of often contradictory legal legitimacies, the fragmentation of the land, the tangle of ethnic identifications, and the extreme diversity of agricultural situations, this development has now been well documented, both by academic research and by experts (Adelkhah, 2013; Alden Wily, 2013a). ${ }^{4}$ But it is largely seen as a failure in 'post-conflict' management or as the result of the evanescence of a state that, in the absence of any 'national sentiment', is now 'bankrupt', succumbing to the dual pressures of a 'corrupt' political class and 'tradition'. Certainly, the responsibilities of Afghan actors are substantial. However, had not the rot already set in because of the inconsistencies of foreign intervention? The basic problem lies, perhaps, in the idea or in the very principle of the aid in the name of which Afghan actors interact. The legacy of the violence of the years 1979 to 2001 and the painful memory they left did not miraculously disappear thereafter. The war is still very present in the minds of Afghans. It continues to provide the grammar and even the lexicon of dayto-day social life. In fact, it has formed the matrix of present-day Afghanistan, as a result of the population movements and the destruction and transfer of property that it caused. In addition, it has shaped the social consciousness of Afghans, who continue to zigzag between past and present in their daily conversations, if only because of the still visible traces of the battles of the 1980 and 1990 or or the transformations of the landscape-especially in terms of urbanisation - that the conflict caused. The landscape has a mnemonic function and the war remains the great founding narrative of contemporary Afghanistan. It is all the more an active presence in that the belligerents were not abstract geopolitical entities such as communism, Islam, or the nation, but flesh-and-blood actors bound by close, and even intimate relations arising

3 Personal observations, 2014 and 2015.

4 See also the publications of Integrity Watch Afghanistan (http://iwaweb.org, accessed on 16 June 2016), the Afghanistan Public Policy Research Organization (http://appro.org.af, accessed on 16 June 2016) and the Afghanistan Research and Evaluation Unit (http://www.areu .org.af, accessed on 16 June 2016). 
from neighbourhood (shafa'a) or kinship (owdourzadegi), either politically or economically constructed (qawm) (Roy, 1985; Alden Wily, 2004, 27). Of course, war brings violence, destruction and death. But the experiences of Afghans cannot be reduced to this tragic dimension. From the political and social point of view, war is also an existential experience. The Islamic intellectual Azizullah Royesh ${ }^{5}$ admirably sums up this idea in his book bogzar nafas bekasham (Let Me Breathe). In particular, he says that it is through war that we learn about life: 'War is everything, it is life, work is war, home is war, thought is born of war, relationships proceed from war. Feelings, the understanding of conviction and religion, all this is war. Men breathe for war, work for it, think for it, pray for it and... they die for it' (Royesh, 2013, 130, our transl.).

This chapter is based essentially on two field surveys conducted in 2014 and 2015 in the central region of the Hazarajat. To the extent that the name of this region refers to the idea of the Hazara ethnic group, it should be noted at the outset that ethnicity refers less to objective groups of belonging, with an origin and a clearly defined territory, than to categories by which actors define themselves (or are defined). ${ }^{6}$ According to Olivier Roy (1985), the war was a crucial vector of ethnic consciousness in Afghanistan. It endorsed our major groups that cannot be defined according to objective and unambiguous criteria: Pashtuns, Tajiks, Hazaras and Uzbeks. By definition, these categories are historically situated. They are contextual, relational and relative: you are a Hazara in relation to the Pashtuns, the Tajiks, and the Sayyids, at a given historical moment that refers to a more or less distant and more or less traumatic past as well as to completely contemporary issues interpreted using the yardstick of this memory. Following Richard Tapper (1983), and in agreement with Olivier Roy (1985) and Alessandro Monsutti (2004 and 2005), we therefore disclaim any primordialist definition of ethnicity. Today, this definition stems in particular

5 Azizullah Royesh is a Shi'ite and Hazara reformer who has been greatly influenced by the Iranian philosopher Ali Shariati. As the founder and director of the pioneering Marefat school in Kabul, he was ranked - in the context of its Global Teacher Prize - by the Varkey Foundation among the top ten teachers in the world in 2015 .

6 Afghanistan has been a hotspot of the problematisation of ethnicity inspired by the founding work of Fredrik Barth (see especially Tapper, 1983, and Digard, 1988). This approach has been adopted by Adlparvar (2015). For a scholarly overview of ethnicity in Afghanistan, see Centlivres (1991). 
from the relation to the state, via war and also via political parties. The Hizb-i Wahdat, more especially, had a decisive role in the ethnicisation of the social consciousness of the Hazara, while this despised minority group saw itself forced to face the challenge of life after the Soviet departure in 1989. However, though we will be paying attention to the political economy of this form of social consciousness in a context of civil war, this should not lead us to reduce it to a purely material struggle, a contest fuelled by greed and grievances between rational actors eager to maximise their profits, in accordance with a rightly criticised paradigm (Marchal and Messiant, 2002; 2003). Nor should it lead us to forget the extreme fluidity of feelings of belonging and thus solidarity in everyday life, on both collective and individual levels. The lines of identification are manifold and subject to negotiation. And it is not uncommon for different parties or factions to come together in the same qawm. In this regard, Alessandro Monsutti $(2005,99)$ mentions in particular the existence of 'a veritable strategy to diversify affiliations as a way of providing some assurance in the event of unfavourable political and military developments'.

Important as it is, the ethnic dimension should not be exaggerated. It is significant only through its inclusion in the political dimension, whether or not this is militarised. It is also mixed with the linguistic dimension that in many ways relativises it and opens new fields of conflict, especially between Dari speakers and Pashtun speakers. But the language dispute at least has the advantage of blurring or even diluting the binary inter-sectarian antagonism between Sunnis and Shi'ites, as well as interethnic oppositions.

From the nineteenth century onwards, the modern Afghan state was formed on the basis of an Anglo-Russian agreement creating a buffer state between the two empires, on a vector of Hanafi rite Pashtun and Sunni elements to which the other ethnic groups and Islamic legal schools (Nizari and Jafari) were subordinated, not to mention the Hindus and Sikhs, who were completely marginalised or expelled after the breakup of the British Raj in 1947. The Hazaras, Shi'ites of the Jafari rite, were the big losers in this process until 1979, and the Hazarajat became the cursed land of their subjection in the 1891-93 war-even though Kafiristan (now Nuristan), in the east, and Turkestan, in the north and north-east, were also conquered by force and colonised by the new Pashtun dynasty (Ghobar, 2011, 483ff. and 49off.).

The Hazarajat is a historical area that has never been an administrative unit. ${ }^{7}$ Until the constitutional revision of 1964 , it was essentially divided between

7 I have used the following translations of Afghan administrative terms: prefecture (wilayat) and prefect (wali); sub-prefecture (woluswali) and sub-prefect (woluswal); district (ghariya). The term manteqa (literally region, locality) has no official administrative significance, but 
four of the five wilayat of the country: Herat, Turkestan, and-especiallyKabul and Kandahar. Today, it covers ten or so territorial entities that are home to the Hazaras (Arez, 2003). The city of Bamyan is the historic heart of the Hazarajat, though it was never exclusively Hazara and Shi'ite. Today the wilayat of Bamyan and Daikundi are the two parts of the country in which Hazara Shi'ite populations predominate, although since 2003, the addition to the Bamyan prefecture of the sub-prefectures of Saighan and Kahrmard of the wilayat of Baqlan - with Sunni Tajik populations of, respectively, 63 per cent and 82 per cent-has relativised the demographic and religious domination of Hazara Twelver Shi'ites. In addition, the Hazarajat is home to most of the Ismailis of Afghanistan and a minority of Sayyid Twelver Shi'ites. The title Sayyid refers to a lineage indicating descent from the Prophet's family, but some of them are of course Sunni Sayyids. Alessandro Monsutti $(2005,91)$ calls this a 'religious aristocracy'. The Qizilbash group is distinguished by its Turkish origins and its claim to descend from the entourage of the Persian ruler Nadir Shah, who invaded Afghanistan in 1738. In 2010, it was estimated that the population of the sub-prefecture of Bamyan comprised 75 per cent Hazara, 15 per cent Sayyid, 10 per cent Tajiks and 0.5 per cent Qizilbash. Furthermore, out of a population of $86,55^{\circ}$ inhabitants, the woluswali today numbers 8,345 people who settled there between 2002 and 2012, having returned from exile or from other parts of the country; this is a little less than 10 per cent of the total population.

Before the 'iron rule' of Abdurrahman (1880-1901), the founder of modern Afghanistan, the Hazarajat had never been politically unified and was ruled by tribal leaders (amir). From the reign of Sher Ali Khan (1863-79) onwards, the so-called Kuchi Pashtun nomads raided the region to lead their flocks in transhumance to the high mountain pastures. Under the pretext of fighting the 'heresy' that existed in this region, Abdurrahman decided to conquer it, after driving its population to revolt in 1891 by subjecting it to an intolerable tax burden and plundering its land and herds, carrying out many arrests and deporting part of its population to Kabul. This military campaign of 1891-93 resulted in massacres, but it also had serious consequences for the future of this region, colonised through the almost total deportation of the Pashtun Kuchi Ghilzai. The Hazaras who survived and remained in the Hazarajat—many of them took refuge in the Iranian city of Mashhad, in the city of Quetta in the British Raj, and in Russia - were enslaved and stripped of their land, including pastures.

indicates the basic unit of territorial consciousness, which encompasses several villages in a clearly identified area of land, below the ghariya. This level of territorial belonging played a decisive role in the war and constitutes a factor of solidarity just as important as the principle of lineage and community associated with the principle of qawm. 
They have therefore been forced, until today, to farm in a mountainous country with long winters where arable land is sorely lacking. Abdurrahman's successors-Amir Habibullah Khan (1901-19) and Amanullah (1919-29) - brought the reign of terror in the Hazarajat to an end. They abolished slavery, withdrew some of the measures discriminating against Hazaras, and restored to them some of their rights by granting titles to their leaders (amir), though this exacerbated the rivalries between these leaders and involved additional exploitation of the peasantry (Ghobar, 2011, 484). Later, the reigns of Nadir Shah (1929-33) and Zahir Shah (1933-73) put the seal on the Pashtun and Sunni domination of Afghanistan and the relegation of Hazara Shi'ites to the position second-class subjects. The great famine of $1971-72$, with its accompanying drought, was terrible. During the tenure of President Dawood (1973-78), the subjugation of the Hazaras was intensified; land-grabbing by the Kuchis was encouraged under cover of the 1970 law on pastures, a law that recognised the state ownership of all land suitable for forage production - not just high mountain pasturesand prohibited the conversion of pasture land to cropland. But the Kuchis' interests were not limited to their pastoral activities. Over these decades during which the Hazaras were excessively exploited, they developed shops and transport companies, which guaranteed their economic stranglehold on the region, especially as usurers. In the wake of the great disaster of 1891-93, the Kuchis therefore seized the few land rights that had been preserved by the vulnerable Hazara peasantry, using debt as a means. (De Weijer, 2007; Alden Wily 2013b; Tapper, 2008; Mousavi, 1998; Monsutti, 2004 and 2005).

Only after the Soviet invasion - which, despite the presence of a small garrison in the town of Bamyan, left the Hazarajat virtually unaffected, as this deprived region offered little of interest and the resistance there was strong and immediate (Mohaghegh, 1984) — could the Hazaras begin to free themselves from the Pashtun, Tajik and Sunni yoke. First, they were able to interact with the central government thanks to the appointment as Chairman of the Council of Ministers of Babrak Karmal (1981-88), Mohammad Najibullah (1989-91) and finally Soltanali Keshtmand, a Hazara from Fouladi, a woluswali from the wilayat of Bamyan, whose parents had been deported to Kabul by Abdurrahman (Keshtmand, 2009). In 1987, under the influence of Tehran, armed groups claiming to be acting more or less for the Islamic Republic of Iran - the Sazman i-Nasr group, close to Ayatollah Montazeri, and the Sapah-i Pasdaran group, close to the Revolutionary Guards - united as a Council for the Alliance (Shura-i ittifaq), based in the district of Yakawlang, and this eventually gave birth to a political party. The Hizb-i Wahdat was created in Bamyan in 1989 and its presidency was entrusted to the charismatic Abdul Ali Mazari (Dorronsoro, 2000, 158ff. and 24off.; Monsutti, 2005: 92ff.; Roy, 1985; Mo'aseseye farhangi 
Saghalain, 1999). Most Tajiks and almost all Pashtuns then left the area, leaving the Hazaras in a position to recover their land and property. They took control of the new bazaar of Bamyan, though the Tajiks remained commercially active there through land and property leased to the Hazaras and the excellence of their connections with Kabul, Mazar-i Sharif and Baghlan. They also speculated on land by selling, as plots of sharak (residential area), properties belonging to Pashtuns from the village of Dasht-i Issa Khan on whose territory the airport was built. Upon the fall of the communist regime in 1992, Hizb-i Wahdat became the champion of the Hazara Shi'ite cause in Kabul. But during the battle that devastated the capital in 1993, it failed to prevent the massacre of Afshar, perpetrated in the western districts. During this episode, hundreds of Hazaras were killed, officially by the Tajik and Pashtun troops of Commander Ahmed Shah Massoud and President Burhanuddin Rabbani but the complicity or betrayal of Hazara elements could not be excluded. ${ }^{8}$ Having retreated to the Hazarajat, the forces of Hizb-i Wahdat nevertheless succeeded, after hard fighting, opposing in 1995 attempts made by Ahmad Shah Massoud's movement to conquer it (Dorronsoro, 2000, Chapter 7).

After the assassination of Abdul Ali Mazari by the Taliban in 1995, Hizb-i Wahdat split into two factions. One, led by Abdul Karim Khalili from Behsud (Wardak), joined the Northern Alliance of Commander Dostom; the other, led by Mohammed Akbari from Waras (Bamyan), allied with the Taliban but also with the Islamic Republic of Iran. The two sides confronted one another until 1998, when the Taliban conquered the Hazarajat after subjecting it to a harsh economic blockade. They quickly entrusted the administration of the region to the supporters of Mohammed Akbari. But Abdul Karim Khalili's men continued to resist, launching an unsuccessful offensive on Bamyan in May 1999. The fighting claimed many lives and led to the destruction of almost one-fifth of the city's buildings, including the bazaar. Almost all of the population, some 13,00o families, fled, and Tajik traders took over the bazaar. Building on the victory of the Taliban, the Kuchis returned to the region to try to recover their property and land rights. In January 2001, fighting duly resumed in the district of Yakawlang, causing a new exodus of the Hazaras under the pressure of Taliban reprisals - a mass killing ( $q$ att-i ' $\mathrm{am}$ ) that remains intensely present in regional memory.

In November 2001, the Hazarajat moved on to a new stage in its history. The Taliban left the area following the us intervention, giving the Hazaras

8 This version of events is disputed by the Hazaras themselves, who place the blame on factional rivalries between Hazara commanders and even on the Sayyids (interviews in Bamyan and Kabul, 2014). See also Royesh (2013, 139 ff.). 
the opportunity to gain access to the Kabul government through Abdul Karim Khalili, who had become the second vice-president alongside Hamid Karzai in 2004. They also challenged the interests (including property interests) of the Kuchis and Tajiks who had taken advantage of the Taliban regime while not being marginalised by the coalition that emerged from the Bonn agreement, signed in 2001. This new context, though more favourable to their interests, did not allow the Hazaras to unite politically. We can at present identify four trends within the Hizb-i Wahdat: that of Abdul Karim Khalili and his Hizb-i wahdat-i islami; that of Mohammad Akbari and his Hizb-i wahdat-i islami-i Afghanistan; that of Mohammad Mohaghegh and his Hizb-i wahdat-i islami-i mardom-i Afghanistan; and that of Erfani Yakawalangi and his Hizb-i wahdat-i islami-i mellat-i Afghanistan. In 2015, the tumultuous appointment of Tahar Zohair to the post of prefect by President Ashraf Ghani, with the support of Abdul Karim Khalili, showed that the antagonisms were still intense. Four Hazara MPs, including Mohammad Akbari, opposed the appointment by organising a sit-in outside the prefecture lasting sixteen days ( 7 to 22 June). On 19 June, young academics organised a counterdemonstration. The arrival of Tahar Zohair on 1 July did not calm matters as the protesters locked the premises of the prefecture while the supporters of the new prefect marched by holding bouquets of flowers. ${ }^{9}$

Within a century, the formation of the state and the social phenomena that came with it - such as urbanisation, emigration, and the confiscation or redistribution of land - had resulted in the sorrowful construction of a Hazara identity seen as an ethnic, even racial fact. Since the late nineteenth century, the Hazaras had indeed been considered Mongols by Tajik, Pashtun and Sayyid elites, and some of their physical characteristics, such as their flat noses, had been the subject of daily jokes. Various factors contributed to this 'invention of ethnicity'. First, the Shi'ite religious awakening of the 196os, related to the Iraqi and Iranian holy places and under the influence of Ayatollah Mir Ali Ahmad Hojjat $^{10}$ and Sayed Esmael Balkhi. ${ }^{11}$ Second, the flowering in Iran of a Hazara literature of resistance (Olszewska, 2009). Third, a musical renaissance, promoted by Radio Hazarahgi in Quetta from 1975 onwards. And lastly, the fact that in 2002 the Us military intervention paradoxically allowed the celebration

9 Personal observation, 2015.

10 Mir Ali Ahmad Hojjat was the main Afghan Shi'ite authority and founder of the first religious school of this branch of Islam in Kabul, in the district of Chandawul. He died in 1974 .

11 Sayed Esmael Balkhi was the founder of the modern Shi'ite Islamic movement, and is known as the father of the Hazara movement for political autonomy. He died in 1968. 
of Nowruz and the public commemoration (publicised in the media) of Ashura to be resumed in Afghanistan - these rituals had been perpetuated by Hazaras living in Quetta or in Iran (Monsutti, 2007).

De facto, the formation of the state also turned the Shi'ite branch into the subordinate religion in an Afghanistan that was presumed to be Sunni, although the constitution did not mention any religious distinction and confined itself to making Hanafi Islam the state religion. Since 2008 and under the new 2004 constitution, the law on personal status-ahwal-i shakhsiya-has allowed Hazaras to resort to figh jafari when both parties are Shi'ites..$^{12}$ Nevertheless, the ethnicisation of the Hazaras is now undergoing an interesting development that tends to separate it from Shi'a Islam. Indeed, some Sunni Hazaras, assembled in council, demand this dual ethnic and religious affiliation and are now — surprisingly — well received by Shi'ite Hazaras pleased to see their ranks being swelled in anticipation of an ethnically connoted electoral competition and to have one foot in the camp of the majority religious affiliation, which allows them to interact with other identity groups on equal terms (Bouda, 2015). Ethnicisation is therefore a process whose outcome is less a well-defined Hazara than a 'Hazarification' of heterogeneous or hybrid populations such as the Hazaras of Pashtun culture or the 'mixed' or 'mixed race' (doraga) Hazaras. ${ }^{13}$ In all ethnic groups, then, a distinction is drawn between original Hazaras (asli) and those to whom Hazara identity is ascribed (wasli), which makes it possible for the 'authenticity' and 'native status' of families to be claimed or contested.

Hazaras and Shi'ites do not constitute a homogeneous group. Beyond their different backgrounds and inequalities in terms of education, wealth, and gender, they have been divided politically since the 1978 coup. As we have said, some joined the Sazman-i Nasr of Mohammad Abdul Ali Mazari while others supported the Hizb-i harakat of Ayatollah Mohseni (Mohaghegh, 1984), thus leading to the break-up of the Hizb-e Wahdat a few years after its establishment. After the split, some made their peace with the Taliban or even joined them (Alden Wily, 2004, 23), while others supported the Hizb-i harakat, including many Sayyids, Qizilbash or Ismailis (Mo'aseseye farhangi Saghalain 1999, 19off.). These internal political differences which have led to military confrontation for three decades, to conflicts over land and real estate, and to commercial and financial quarrels, fuel distrust and animosity between Shi'ites,

12 This is the law relating to marriage, divorce and inheritance, http://www.bsharat.com/ id/16-f-h/o1.html (accessed on 16 June 2016).

13 See Yazdani $(2011,267 \mathrm{ff}$.). The author is convinced of the existence of 'true' Hazaras, while stating that matrimonial alliances may have altered their physical characteristics and that there are 'Pashtunized' or 'mixed' (dorageh) Hazaras. 
especially between Hazaras and Sayyids, the latter often accused of taking advantage of Taliban domination (or, under the monarchy, of having compromised with the Pashtun ruling class). In some ways, the war gave the Hazaras an opportunity to emancipate themselves socially from the domination of the Sayyids, as well as from the Pashtuns and the Tajiks. This process followed a pattern partly comparable to that observed in Lebanon, in that Abdolali Mazari, its ideologue, was close to Chamran, the Hizbollah leader, and absorbed this experience alongside other Iranian or Palestinian anti-imperialist fighters. ${ }^{14}$ Since 2002, reconstruction has followed the lines laid out by this emancipation, but it is complicated by rivalries between the Hazaras who remained in the provinces during the war (watani), those who chose exile, especially in Iran (zawari), and returned fortified by their diasporic experience, and those who had come from other parts of the country ${ }^{15}$ to settle in the Hazarajat, now perceived as the land of the Hazaras by definition. ${ }^{16}$ the Invention of Ethnicity

The Western military intervention of 2001, and the 'reconstruction' of the state that ensued, reproduced and extended the process of the invention of a Hazara Hazarajat and the ethnicisation of the Hazaras. The foreign presence, the financial flows it generated, the economic opportunities it opened up, and the institutional patterns that it established intensified the ethnicisation and/or sectarianisation of Afghan society, as well as the return of refugees and migrants, investments from the diaspora, and urbanisation. And this happened even though, politically and ideologically, aid for reconstruction was meant to transcend these divisions inherited from the past, these incarnations of 'tradition' allegedly behind the political crisis into which the country had sunk since the 1970s. Inspired by the experts of the International Security Assistance Force (ISAF), the 2004 constitution also drew on a primordialist vision of ethnicity and sectarianism to explicitly recognise the rights of ethnic groups, who found themselves reified as a result. The fact that the theory of nationalities (mellat) proposed by the People's Democratic Party of Afghanistan (1978-79)

\footnotetext{
14 Interviews with Saleh Aliyar, Chairman of the Peace Council, and Mostafa Makarem, director of the television channel Rahe-e-Farda (Kabul, 2014 and 2015).

15 These Hazaras came in particular from Ghazni, the historic stronghold of intellectual elites thanks to its links with Pakistan.

16 Personal observation (2014-15); Adlparvar (2015, 152 ff.).
} 
and the Soviets (1979-89) has re-emerged under the 'umbrella' of NATO is an irony of history. 'Reconstruction' was conceptualised in an ethnic and sectarian fashion, and on that basis laws were enacted, funding awarded, ministerial and administrative posts allocated, voters mobilised and property or matrimonial disputes voiced. Given their historical subordination, the Hazaras, now for the first time the objects of affirmative action rather than of discrimination, were the major beneficiaries of this policy of allocating public resources on an ethno-sectarian basis, while continuing to experience this policy in a sorrowful way. As we know, they achieved the legitimisation of the Jafari legal school through the 2004 constitution and the ahwal-i shakhsiya law passed in 2008. But their age-old rivals, the Kuchis, were also given the status of an ethnic group in their own right; a group whose living conditions and education the constitution seeks to improve (Tapper, 2008). The double reification of these 'complementary enemies' is of course fraught with potential dangers, as has already been shown by the bloody clashes between Hazaras and Kuchis in Wardak in 2010, and in Nahoor, in Ghazni, between 2010 and 2012, and the subsequent ethnopolitical activism of Hazara and Pashtun MPs defending their respective clienteles as the general elections approached. ${ }^{17}$ The fact that the post of prefect (wali) of the wilayat of Bamyan was given to a Hazara for the first time in history is one of the most eloquent illustrations of the ethnicisation of the reconstruction of Afghanistan under the aegis of foreign aid. This position was successively occupied by Mohammad Rahim Aliyar in 2003, Habiba Sarabi in 2005 - the first woman to hold a position of this significance in the country, Gholamali Vahdat in 2014, and finally, not without difficulties, Tahar Zohair in July 2015. Similarly, and by way of example, a dozen low-ranking officials of the sub-prefecture of Shibar, in the wilayat of Bamyan, are Hazara Twelver Shi'ites, while the administrative district includes 30 per cent Sunni Tajiks and many Ismailis (almost half of the population in Shibar are Shi'ites).

These appointments were followed by the recruitment of Hazara officials and administrative officers, chosen in accordance with the ethnic logic of the spoils system - or even in accordance with party or faction, as the abovenamed prefects are all close to the Hizb-i Wahdat, of the Khalili/Mohaghegh tendency. These appointments have therefore had an immediate impact on the policy of land allocation, the recognition of land rights and the allocation of state resources in favour of Hazaras and to the detriment of Tajiks and Sayyids (Adlparvar, 2015, Chapter 5). Beyond politics and administration, ethnicisation

17 See the relevant press articles (in Persian), including: http://kabulpress.org/my/spip .php?article1oo66 (accessed on 16 June 2016) and http://urozgan.org/Clear/fa-AF/print/ article/print/1604/ (accessed on 16 June 2016). 
has thus been extended more clearly to encompass the economic sphere, including the issue of land and the control of the bazaar of Bamyan, which now counts only a small minority of Tajik traders instead of the 2,500 or so who ran the old bazaar at the foot of the Buddhas in the 1970s and 1980s. Moreover, Hazara consumers buy only from Hazara traders. "The Hazara does not eat the bread of the Tajik' is an oft-heard remark.

The political economy of 'reconstruction' has inevitably grafted itself into the ethnopolitical memory of the war and prior periods, in a country where the traceability of property is a highly contradictory matter, depending on the nature of the evidence adduced (political, legal, customary, scriptural or oral), thus giving a contemporary, conflictual character to any reference to the past (Alden Wily, 2004; Monsutti, 2008). When elections take place, Afghans can immediately identify among the candidates the fighters who resisted the Soviet occupation - those who, in Afghanistan, are referred to as jihadis-and the migrants who have returned home (mohajer). Similarly, they distinguish economic actors depending on the origin of their fortunes and their projects. Everyone is familiar with the career of a given hotel owner, residential development promoter (sharak) or bazaar trader.

The ethnic and religious identity of entrepreneurs and recipients of development aid is thus self-evident and foreign actors adapt to it when not exploiting it. For example, the influx of NGOs with Western and Japanese financial support in the prefecture of Bamyan, anxious to meet the needs of one of the poorest regions of the country and to rescue its women, was immediately configured in accordance with interethnic and inter-religious relations as the war had redefined them (Anjoman-i nevisandegan-i Bamyan, 2011). The armed resistance of Abdul Karim Khalili to the Taliban offensive from 1996 to 1998, and his political rise under President Hamid Karzai, consummated the process of the 'Hazarification' of a province previously dominated by Tajiks and Sayyids (though the former continued to exert economic and financial control from Kabul, Baghlan, Mazar-i Sharif and Kunduz), and of a population that previously perceived itself as Shi'ite rather than the ethnic mode favoured by the structure of military resistance in political parties-in this case by the Hizb-i Wahdat, or rather by its four branches. In return, most foreign aid actors have taken for granted the essentially Hazara nature (the 'Hazarity') of the Hazarajat. And after 2004, the Hazara themselves came in great numbers from Ghazni, Balkh, Herat and other locations favoured by the diaspora, hoping to profit from the windfall of aid, claiming they were 'returning to their roots'. Abdul Karim Khalili encouraged this movement in order to strengthen his electoral base as the 2003 presidential election approached - an election in which he supported the candidature of Hamid Karzai-which involved mobilising 
women's suffrage, to the great satisfaction of the NGOS of international civil society. So, the ethnicisation and sectarianisation of a region can sit comfortably alongside the priorities of development aid and the 'reconstruction of the state'. Similarly, by seizing on 'runaway marriages' (izdiwaj farari) between, for example, a young Hazara man and a young Sayyid woman according to a bureaucratised and judicialised logic of identity that is completely different from the former procedures for conflict resolution between families or qawm, the Independent Commission for Human Rights in Afghanistan, the UN Assistance Mission in Afghanistan and women's rights NGOs reify matrimonial relationships by combining them within ethnic categories (Adlparvar, 2015, 138; weekly Sada-I Shahrvand-i Bamayn, 1, jawza 1393/2014, 1). Conversely, international aid sometimes produces 'negative' ethnic identities, especially when it abandons its attempt put down roots in radical or conservative areas deemed too dangerous, including the Tajik-dominated provinces of Sayghan and Kahmard, Shibar, or the south of the country, which is in the hands of the Taliban.

But these processes cover more complex lines of division. As we have seen, the Hazaras in Bamyan are divided. Indigenous Hazaras (watani) now live together, in a state of some tension, with Hazaras who came from Ghazni, Herat and Mazar-i Sharif after the fall of the Taliban to enjoy the windfall of the Hazarajat, as well as with the zawari Hazaras back from Iran. Like other ethnic groups in the country, the Hazaras as a whole are ultimately driven by progressive internal divisions that are less part of identity in the abstract sense than of social inequalities, starting with inequalities in gender and education. As shown by the case of the village of Fatmasti, the situation is even more complex on the micro-local level of historical lands. In this fragmented social landscape, generally governed by the twin principle of lineage ( qawm) and locality (manteqa), Olivier Roy (1985) was among the first to demonstrate the need to keep in mind that the ethnicisation of Afghan society is a fluid process, situated historically and politically constructed, at least since the centralising reign of Abdurrahman. The nature of this process has been confirmed by Alessandro Monsutti's research on the Hazaras (2004 and 2005). This ethnicisation is not based on a territorialisation of tribal membership which might be explained by one of those notorious (and improbable) 'ethnic cards'. It rests instead on population movements that are either voluntary and motivated by economic interest, or constrained by central government initiatives - as we saw in connection with the Hazarajat, by the convulsions of land reform (1976-79) or by war (1979-2001).

It is thus necessary to combine the issue of the local and segmental with that of population mobility in the context of transhumance-but also of seasonal migration, emigration, and membership of the diaspora-and with 
that of the fluidity and fungibility of ethno-sectarian identifications. It is also essential to give a central place to a third principle, that of neighbourhood (shafa'a) between residents and between ethnic groups; a principle that is the source of conflict and compromise, of competition and solidarity (Mumtaz, 2013; Monsutti, 2008).

\section{The Political and Moral Economy of Ethnicity}

'Reconstruction' is only one moment among many in this long history, an episode that is changing its direction thanks to the extent of the resources pumped into the country and the introduction of representative institutions conducive to the ethnicisation of political life through elections. From this point of view, foreign intervention has, since 2001, deemed it politically correct to promote the integration of the 'minority' par excellence - that is to say, the Hazaras - into the Afghan political system, at the cost of the ethnic reification of their identity but without bringing them out of their socio-economic subordination, including in the Hazarajat, a particularly deprived area for mainly geographical reasons. In the regions, the bulk of land speculation focuses on plots that would have little market value outside this mountainous country, as they are located on steep terrain, are hard to sustain and are exposed to rainwater run-off, erosion and landslides.

Favoured by the securitisation of land ownership, the territorialisation of ethnicity strengthens the community bias of development aid. Sometimes donors exploit this for strategic, religious or cultural reasons of their own, as is the case with Iran (which promotes the Hazaras), Pakistan (the Pashtuns), Turkey (the Uzbeks) and the Aga Khan Foundation (the Ismailis). But beyond these political approaches, the operational requirements of the land are selfevident. While most foreign actors endeavour to remain politically correct by recruiting several Hazaras, they must in all cases rely on Pashtuns to work in the south, or Tajiks or Uzbeks in the north. Of course, the same reasoning applies to the Hazarajat, where it is essential to use Hazaras. Despite this, the NGO labour market initially benefited the Sunnis, if only because they form the majority and are often better trained and more commonly English-speaking.

Ethnic networks, meanwhile, are endeavouring to tap into the flow of development aid and the foreign presence. Thus, the Hazaras benefit from institutions or projects connected with human rights, and the Tajiks from scientific and cultural cooperation: the former focus on commissions for women's rights, the latter on think tanks and the media. As for Pashtuns, they are irreplaceable in the crucial area of telecommunications, for obvious reasons of 
security - only they can travel confidently in Pashtun areas-and because they trained in Pakistan while in exile during the 1980s and 199os.

Since 2002, the diaspora, development aid and the foreign troops and NGOS in the territory have pumped substantial funds into Afghan society. These funds have caused a sharp increase in prices in certain sectors, including real estate, hotels and restaurants, airlines, car rental companies, and the consumption of international products and certain local services, such as the provision of must-have items for wedding venues. But this influx of money was grafted onto existing social relations, especially in families, and transformed their balance and even their very nature. This resulted in a complex mixture of traditionalisation and monetisation of one's kin. In all social circles, as the dollar is king, the father does not so much give his daughters away in marriage as trade them, sometimes at a very high rate, and sometimes right from the cradle. ${ }^{18}$ If an interesting offer comes along, a farmer may for example be compelled to give away his child. But the head of a good family whose reputation triggers tantalising financial proposals from suitors who wish to climb up the social ladder can proceed in just the same way. At this point, complex social strategies intervene and usually contribute to dowry inflation. For instance, a father wanting to reserve his daughter for one of her cousins can try to turn away, without offending him, an inopportune suitor by demanding a very high dowry (or 'milk price', pul-ishir). But if the ploy fails, as often happens, the increase is considered effective. The marriage market has thus become judicialised as a result of its monetisation and the intervention of the Independent Commission for Human Rights in Afghanistan, the United Nations Assistance Mission in Afghanistan and NGOs concerned to defend the condition of women and the cause of rights. In return, this judicialisation has led to an acceleration of the monetisation of this market in a context where the courts, which not only need payment but are also, it is said, lured by the smell of money, continue to promulgate financial decisions relative to the amount of the dowry or to blood, which follow the exponential curve of the cost of living. The combination of money, legal system and custom tends to extend, reify and dramatise the practical exercise of the last of these, for example in the shape of marriage exchanges of the compensatory type intended to avert or stop the 'evil' ( $b a d$ or badal) - that is to say, violence between families, clans and ethnic groups. Some might even seek, these days, to trigger a family or marital conflict, hoping to reach an agreement of this type. The idea of antagonism is immediately associated with that of the profit that might be drawn from it, which induces a form of intentionality: thus, the complainant will be suspected of having

18 This is called gahvara bakhshi (making a gift from the cradle); see Ghazali (2013). 
provoked a dispute so as to avoid having to pay a dowry (similar practices make it possible to consolidate the legal status and securitisation of land).

The distortions introduced within Afghan society by the foreign presenceand by the influx of money, the land speculation, and the ideological dissonance it generates - come with a high human cost. First and foremost, they lead to a split or even a generational divide. The youngest people are often better educated and more familiar with international practices, and their command of English allows them to benefit from professional and economic opportunities that are more or less beyond the reach of their elders. This imbalance has led to the widespread destabilisation of social status: the young suffer from not holding decision-making power that is proportional to their skills in what is still a patriarchal and tribal society; older people believe that the success of their juniors is a challenge to their authority. Added to this is a destabilisation of conjugal roles, evident for example when a woman has her own income, for example because she works for an NGO, while her husband is unemployed or has to settle for the meagre rewards of the normal Afghan economy. In addition, women are beginning to express their demands with regard to inheritance rights: this is an explosive development from the point of view of customary law and Islamic law. Moreover, development aid and its collateral effects are intensifying intra-generational and intra-family rivalries, fanning 'competition among peers, or even between cousins' (sayal dari or sayal shiriki) or even rivalry between the descendants of brothers (owdourzadegi). So a woman may have to pay a significant amount of rent to her husband in order to turn a room in the family home into a nursery. A young man who organises a too lavish wedding can create a bad precedent for his brothers, cousins or friends, who may not have the same financial means as he does and will see their reputations suffer accordingly. Women working for NGOs should be careful not to tarnish the honour of their colleagues. If they were to separate from their husbands, they would not only lose their social status but also their jobs, and find the chances of them being elected significantly limited, if they are thinking of getting involved in this sphere. Should they be obliged to go to court to see their rights enforced, or simply see their demands recognised, the process will cost them around USD 8,00o.

Generally, the multiple lines of division and conflict running through Afghan society are amplified by its extremely fragmented character and the tangle of landholdings, ethnic and religious memberships, and clan and family allegiances. Any allocation of resources, especially investment, involves a choice in favour of one locality and therefore at the expense of others. This phenomenon is evident in the field of rural engineering: water supplies, the charges that determine their use, the waiting time required to obtain access to 
them, and their sometimes unwanted consequences on the natural environment all create a new field of conflict in which the violence between villages or towns (ghariya) finds expression. The financial and consumerist bubble that has been constantly swelling since 2002 is causing devastating social disruption. Those in power give free rein to their sexual predation, exerted at gunpoint or with the aid of great sheaves of money and of college qualifications. The individuality of women who have returned from abroad-from the West, or from Iran or Pakistan - and the independent spirit of those who have been educated triggers the brutality of husbands, fathers or brothers who refuse to accept that these women might be any different from others. Marital jealousy can also play a part-a feeling all the more dangerous as it is supposed to express family honour. The human toll of these tensions is appalling. Many women even commit suicide by atrocious means (self-immolation or swallowing pesticide or rat poison), or suffer senseless corporal punishment, such as having their nose, ears or lips cut off; the press has described these abuses extensively as occurring in Bamyan, Daikundi and Hera. If we stick to these sources, the cases seem, curiously, to be less numerous in the Pashtun, Tajik and Uzbek areas, even though these are reputedly more conservative. ${ }^{19}$ As shown by the murder of the young woman poet Nadia Anjoman, 26 years old, in November 2005, the physical elimination of women deemed to have made a nuisance of themselves has become commonplace. But deadly violence is also the rule when it comes to settling land disputes and quarrels of a romantic, inter-familial, ethnic or sectarian nature. The overt militarisation of this sphere, on the initiative of the commanders, is only the most extreme example of the use of force as a mode of social regulation.

Rightly or wrongly, the population holds the providers of aid responsible for the uncontrolled circulation of firearms: Provincial Reconstruction Teams sent out to rebuild the provinces are left without means of defence, and are therefore unable to sell weapons on to Afghans, especially as the searches carried out by us troops in private homes have prompted many households to provide themselves with the tools necessary to protect their privacy and safeguard their honour. The massive recruitment of local police (polis-i mahalli) - some 30,000 of them - plays a part in the militarisation of Afghan society, as these security forces are readily viewed by the population as arbaki, those swashbuckling figures who controlled the neighbourhoods and played a central role in social violence and civil war (Dorronsoro, 2000, 127). In other words, aid and

19 See in particular these articles (in Persian): http://www.afghanirca.com/newsIn .php?id=22126 and http://www.afghanpaper.com/nbody.php?id=68734 (accessed on June $16,2016)$. 
widespread armed violence feed on one another and are part of a spectrum that extends from private confrontation to civil war-the very same civil war that the foreign presence is supposed to avert.

One final factor needs to be considered. The self-proclaimed return to peace following the Us intervention in 2001 and the formation of an elected government has delegitimised Afghan emigration in the eyes of foreign countries, particularly Western states and Iran, which are now trying to hamper such emigration since it no longer seems to involve refugees and asylum-seekers in the strict sense of these terms. Nevertheless, the work of Alessandro Monsutti has long since dismantled any excess rigidity in the classification of the mobility of Afghans, including Hazaras. Hazaras do indeed live as 'travellers' (mosâfir), as members of an age-old diaspora that has always circulated according to cycles and migration patterns that stem successively or simultaneously from political exile, from flight in order to survive, from professional expatriation, from study abroad or time spent abroad for religious reasons, and from seasonal migration. Travel is a means of protection as well as a means of livelihood or enrichment, but it is also a way of confirming one's maturity, and a veritable lifestyle in itself. In addition, the remittances of migrants are essential to the development of this country, under considerable pressure as it is from demographics and land-related issues (Monsutti, 2004 and 2009; Gehrig and Monsutti, 2003). The Hazarajat alone apparently receives approximately USD 200 million per annum from Afghans working in Iran (Monsutti, 2009, 102, note 37). There is a glaring contradiction between the display of good intentions and the real effectiveness of the policies implemented. Afghan teenagers who slip across the borders of Iran, Turkey, the Balkans and EU countries only to see their hopes stagnate, or who try and make a new life for themselves by hanging around the Gare du Nord in Paris or the approach roads of the Channel Tunnel in Calais, are the pathetic illustration of the side-effects of the territorial approach to reconstruction when applied to mobile populations.

\section{6}

\section{Conclusion}

The sometimes dramatic distortions introduced into Afghan society by Western intervention stem from a scissor effect. First, donors, foreign institutions, and NGOs remain prisoners of a cultural, if not an orientalist approach to the country; a country that they are helping to traditionalise and particularly to ethnicise. They will, for example, be the first to invoke 'custom' (rawaj) and to seek the opinion of the 'elders' in order to implement their projects. They set aside the fact that the advice they are given is sometimes motivated by 
material interests or factional alignments and is likely to exacerbate social conflicts, in particular over land, in which they play a part, and neglect the contradictions between 'customs' that favour men over women, brothers over sons, the elderly over the young, and the rifle over mere paper documents and their own empowerment objectives with regard to subordinate social groups, especially women, and the construction of a rule of law that would be legalrational - that is, bureaucratic in nature. Similarly, foreigners take for granted the Islamic nature of Afghan society and its local law, whereas this society is not systematically Islamic, especially in terms of land and inheritance, which are not governed by figh (Islamic jurisprudence).

Second, development aid is just as likely to destabilise this so-called traditional society by ignoring its mysteries, dreaming of forgetting the past, accelerating its monetisation and commercialisation, encouraging a securitisation of property that undermines the rights of joint ownership and the historical compromise of neighbourhood (shafa'a), creating new minorities while being unable to guarantee their safety, providing education and employment to a tiny fraction of women and young men, thereby giving them the resources to challenge their social subordination and, finally, by bringing in or consolidating new repertoires of political or professional legitimacy, most often at the expense of the authorities of 'custom'.

This series of contradictions inherent in development aid brings social, political and even military conflicts in its wake. However, the complex logic behind these conflicts is rooted in the mysteries of the locality (manteqa) and 'segmentarity' (qawm) that are closed books to foreign governments and donors as well as NGOs, readable only through the distorting, outrageously reductive prism of the culturalist construction of Afghan society. By simplifying and reifying this society, disguising it in the deceptive features of tradition and ethnicity, this prism totally neglects the radical transformation that Afghan society has experienced as a result of war and emigration.

The foreign providers of development in Afghanistan, pressurised by the calendar of the civil year, which controls their budgets, and dependent on intermediaries chosen for their ease of access, command of English, and interpersonal and managerial skills, move like bulls in a china shop. Even worse, they burden society with unprecedented conflicts over land issues, trade, banking, wages and education. The three pillars on which Afghan society still restszan (woman), zar (money) and zamin (land) - are, more than ever, factors of competition and confrontation. Development, economic growth and the internationalisation of trade conflicts stoke conflict as a result of the resources they generate and the desires they arouse. At the same time, the rational-legal, bureaucratic rule of law, if indeed it has the political and financial resources 
necessary to emerge, does not appear to be best placed to peacefully resolve social disputes, particularly over land. Informal arbitration procedures between protagonists, at which the Taliban excel, are probably better suited to the concrete conditions of the country, at least in the countryside, even though they tend to reproduce social domination (Sadeghi, 2013; Baczko, 2013; De Lauri, 2013). In addition, 'capitalism' will not easily resolve the crucial issue of coexistence between shepherds and farmers, and any exclusive securitisation process of arable land or commercialisation of pastures will have devastating consequences (Alden Wily, 2013b). On the ground, those involved are demanding property deeds, which alone, in their eyes, can guarantee any protection (even illusory) for their property, while demanding respect for customary law, particularly that of the neighbourhood (shafa'a), as these laws convey an ethic of collective responsibility.

Furthermore, such a mountainous and arid country as Afghanistan cannot expect an endogenous socio-economic take-off in a context where the scarcity of arable land adds to the demographic pressure. For decades, the mobility of populations has been the primary means of their survival, and sometimes their relative enrichment. For thirty years, remittances from emigrants have constituted a real lever for the transformation of society. Conversely, any obstruction to this movement of human beings aggravates internal tensions. In the late 1940s, the independence of Pakistan, for example, hindered the crossborder transhumance of the Kuchis, bringing extra pressure to bear on the pastures of the Hazarajat. There will be no development in Afghanistan without international mobility for Afghans. Funding and policies that fail to reflect this reality will bring neither social change nor economic growth, and will not even manage to 'fix' populations in their place, as Western states and Iran hope.

For fifteen years, the world has been scared of the extremism of the Taliban and the threat it poses to the international system, and has seen Afghanistan only through the reductive prism of jihadi threat. At the same time, the country has tried to send a different message to Europe, one that Europe has refused to hear-a message whose urgency and complexity are currently being revealed through the influx of refugees: how can one shape a state that follows the rule of law and is consistent with international standards while generating a basic minimum of economic growth and social justice, and take into account people's imperative need to be mobile and interact with the several millionstrong diaspora? It would be unreasonable to deny all merit to the foreign intervention of 2001. The new regime has undoubtedly created a political space in which all the so-called ethnic groups in the country can discuss sharing the external financial windfall, if not on an equal footing at least in an atmosphere conducive to effective competition and compromise (in this specific case, the 
influx of resources plays a role comparable to that of tax in Western states). Given the history of Afghanistan over the last two centuries, such an evolution is a real breakthrough. But this mode of development is still hampered by imbalances and uncertainties.

\section{References}

Adelkhah, F. (ed.) (2013) 'Guerre et terre en Afghanistan', Revue des mondes musulmans et de la Méditerranée, 133, https://remmm.revues.org/7936 (accessed on 16 June 2016).

Adlparvar, N. (2015) 'When Glass Breaks, It Becomes Sharper': de-constructing ethnicity in the Bamyan Valley, Afghanistan, PhD thesis, (Brighton: University of Sussex), http://sro.sussex.ac.uk/56083/ (accessed 16 June 2016).

Alden Wily, L. (2013a) Land, People, and the State in Afghanistan: 2002-2012 (Kabul: Afghanistan Research and Evaluation Unit), http://www.areu.org.af/EditionDetails.as px?EditionId $=622 \&$ ContentId $=7$ \&ParentId $=7$ (accessed on 16 June 2016).

Alden Wily, L. (2013b) 'The Battle for Pastures: The Hidden War in Afghanistan', Revue des mondes musulmans et de la Méditerranée, 133, pp. 95-113, http://remmm.revues .org/8021 (accessed on 16 June 2016).

Alden Wily, L. (2004) Land Relations in Bamyan Province. Findings from a 15 Village Case Study (Kabul: Afghanistan Research and Evaluation Unit), http://www.areu .org.af/EditionDetails.aspx?EditionId $=179 \&$ ContentId $=7 \&$ ParentId $=7$ (accessed on 16 June 2016).

Andishmand, M.E. (2009) Hizb-i democratik-i khalq-i afghanistan. Koudata, hakemiyat va foroupashi (Le parti démocratique du peuple d'Afghanistan. Le coup d'Etat, la souveraineté et l'effondrement [The People's Democratic Party of Afghanistan. The coup, the regime and the collapse] Translated by the author) (Kabul: Mayvand, 1388/2009).

Anjoman-i nevisandegan-i Bamyan (2011), Shanasnamah nahadha-i madaniva ahzab-i siyasi-i welayat-i Bamyan va Daikundi [The booklet of institutions of civil society and political parties in the regions of Bamyan and Daikundi], (Bamyan, 1390/2011).

Arez, G.J. (2003) Sarhadat va taghsimat-i idari-i afghanistan dar toul-i tarikh [The borders and administrative divisions of Afghanistan in history], (Peshawar: Kor, 1382/2003).

Azimi, M.N. (2012-2013) Yadmandehai az jang-i Jalalabad [What is left of memories of the Battle of Jalalabad] (Kabul: Vatan, 1391/2012-2013).

Baczko, A. (2013) 'Les conflits fonciers comme analyseurs des guerres civiles: chefs de guerre, militaires américains et juges Taliban dans la Kunar', Revue des mondes musulmans et de la Méditerranée, 133, pp. 115-132, http://remmm.revues.org/8034 (accessed on 16 June 2016). 
Bouda, A. (2015) Barnahadehai bar bab-e 'shora-i hazaraha-i ahl-i sonnat dar afghanistan', 26 Sowr 1394/2015, http://urozgan.org/fa-AF/article/9024/ (accessed on 16 June 2016).

Centlivres, P. (1991) 'Exil, relations interethniques et identité dans la crise afghane', $R e$ vue du monde musulman et de la Méditerranée, 59(1), pp. 70-82, http://www.persee .fr/doc/remmm_0997-1327_1991_num_59_1_1492 (accessed on 16 June 2016).

De Lauri, A. (2013) 'Terre, normes de propriété et litiges à Kaboul', Revue du monde musulman et de la Méditerranée, 133, pp. 133-149, http://remmm.revues.org/8051 (accessed on 16 June 2016).

De Weijer, F. (2007) 'Afghanistan's Kuchi pastoralists: change and adaptation', Nomadic Peoples, 11(1), pp. 9-37, DOI: 10.3167/np.2007.110102.

Digard, J.-P. (ed.) (1988) Le Fait ethnique en Iran et en Afghanistan (Paris: Editions du CNRS).

Dorronsoro, G. (2000) La Révolution afghane. Des communistes aux talibans (Paris: Karthala).

Gehrig, T. and A. Monsutti (2003) 'Territoires, flux et représentations de l'exil afghan: le cas des Hazaras et des Kaboulis', A contrario, 1, pp. 61-78, http://www.cairn.info/ revue-a-contrario-2003-1-page-61.htm (accessed on 16 June 2016).

Ghazali, B.A. (2013) 'Gahvara bakhshha bayad az zananeshan ham bogzarand', Killid, 585,21 September, p. 23.

Ghobar, M.G.M. (2011) Afghanistan dar masir-i tarikh [Afghanistan and its historical trajectory] (Téhéran: Erfan) 1390/2011.

Keshtmand, S. (2009) Danishnameh Aryana (Encyclopédie Aryana), 23 farvardin 1388, http://database-aryana-encyclopaedia.blogspot.fr/2009/o4/blog-post_12.html (accessed on 16 June 2016).

Marchal, R. and C. Messiant (2003) 'Les guerres civiles à l'ère de la globalisation. Nouvelles réalités et nouveaux paradigmes', Critique internationale, 1(18), pp. 91-112, DOI: 10.3917/crii.018.0091.

Marchal, R. and C. Messiant (2002) 'De l'avidité des rebelles. L'analyse économique des conflits par Paul Collier', Critique internationale, 3(16), pp. 58-69, DOI: 10.3917/ crii.016.0058.

Mo'aseseye farhangi Saghalain (1999) Shorayi etelaf, zamineh saz-i ettehad-i shi'ayan, Tehran, Mo'aseseye farhangi Saghalain, 1378/1999.

Mohaghegh, Mohammad (1984) Khaterat-i yek sangar neshin. Goushei az jenayat-i khawanin dar enghelab-i eslami-i afghanestan [Memories of a man of the trench, Vol. 1, Some of the crimes of landowners in the Islamic revolution of Afghanistan], n.p., Sayed Habibollah Shafagh, 1363/1984.

Monsutti, A. (2009) 'Itinérances transnationales: un éclairage sur les réseaux migratoires afghans', Critique internationale, 44(3), pp. 83-104, DOI: 10.3917/crii.044 .0083 . 
Monsutti, A. (2008) 'The impact of war on social, political and economic organization in Southern Hazarajat', in M.-R. Djalili, A. Monsutti and A. Neubauer (eds.) Le Monde turco-iranien en question (Paris: Karthala), pp. 195-209.

Monsutti, A. (2007) 'Image of the Self, image of the Other: social organization and the role of "Ashura" among the Hazaras of Quetta (Pakistan)', in Monsutti, A., S. Naef and F. Sabahi, (eds.) The Other Shiites: From the Mediterranean to Central Asia (Berlin: Peter Lang), pp. 173-191.

Monsutti, A. (2005) War and Migration. Social Networks and Economic Strategies of the Hazaras of Afghanistan, translated by Patrick Camiller (New York: Routledge).

Monsutti, A. (2004) Guerres et migrations. Réseaux sociaux et stratégies économiques des Hazaras d'Afghanistan (Paris: Editions de la Maison des Sciences de l'Homme).

Mousavi, S.A. (1998) The Hazaras of Afghanistan. An Historical, Cultural, Economic and Political History (Surrey: Curzon Press).

Mumtaz, W. (2013) 'Three Faces of Shafa'a. Land Ownership on Trial in Ningarhar', Revue des mondes musulmans et de la Méditerranée, 133, pp. 169-185, http://remmm .revues.org/8071 (accessed on 16 June 2016).

Olszewska, S. (2009) Poetry and its Social Contexts among Afghan Refugees in Iran, DPhil thesis (Oxford: Wolfson College, Oxford University).

Qhodus, S.A. (2009)Jangha-i Kabol 1371-1375 [The Battles of Kabul 1992-1996] (Bochum: Nashr-i Ida), 1387/2009.

Roy, O. (1985) L'Afghanistan. Islam et modernité politique (Paris: Seuil).

Royesh, A. (2013) Bogzar nafas bakasham [Let me breathe] (Kabul: entesharat-e tak), 1391/2013.

Sadeghi, A.R. (2013) 'La protection de la propriété terrienne entre loi et arbitrages', $R e$ vue des mondes musulmans et de la Méditerranée, 133, pp. 83-91, http://remmm.re vues.org/8004 (accessed on 16 June 2016).

Tapper, R. (2008) 'Who are the Kuchi? Nomad self-identities in Afghanistan', Journal of the Royal Anthropological Institute, 14 (1), pp. 97-116, DOI: 10.1111/j.1467-9655 .2007.00480.x.

Tapper, R. (ed.) (1983) The Conflict of Tribe and State in Iran and Afghanistan (New York: St Martin's Press).

Yazdani, H.A. (Haj Kazem) (2011) Pajouheshi dar tarikh-i hazaraha, [A study of the history of the Hazaras] (Tehran: Erfan) 1390/2011.

\section{Chronology}

1880-1901: 'Reign of Iron' of Abdurrahman, the founder of modern Afghanistan, under British tutelage

1891-93: 'Three-year War' in the Hazarajat 
1928: Major reforms of the constitutional King Amanullah (1919-29)

1933-73: Reign of Zaher Shah

1973: Coup of Mohammad Dawood Khan, the King's cousin and former Prime Minister

(1953-63), and proclamation of the Republic

1978: Coup of the People's Democratic Party

1979-89: Soviet occupation

1992: Fall of the pro-Soviet regime

1992-96: Coming to power of the Mujahideen, who resisted the Soviet occupation, and the 'War of the Commanders'

1996-2001: Taliban regime, overthrown by US military intervention

2001-14: Karzai Administration

Since 2014: Coalition government of Abdullah Abdullah-Ashraf Ghani 